\title{
Critical Thinking Skills and Problem-Solving Level of Malang Culinary Program Vocational School
}

\author{
Yuyun Nailufar $^{1 *}$ Teti Setiawati ${ }^{2 *}$ Rina Rifqie Mariana ${ }^{3 *}$ \\ ${ }^{1,3}$ Culinary Art Education, State University of Malang \\ ${ }^{2}$ Lecture of Industrial Technology, State University of Malang \\ "Corresponding author Email: ${ }^{\text {I) }}$ yunnaa.yuyun@ gmail.com, ${ }^{2)}$ teti.setiawati.ft@um.ac.id, ${ }^{3)}$ rina.rifqie.ft@um.ac.id
}

\begin{abstract}
Critical thinking skills and problem-solving are the ability to analyze an information that can be used to be a learning material that can help to solve a problem. This study aims to describe critical thinking skills and problem-solving level in students of Culinary Program Vocational School in Malang. The research using a descriptive research with a quantitative approach. Data collection technique using a questionnaire that analyzed by using descriptive percentile analysis. The population are 413 respondents and the sample are 191 respondents. The results showed the level of critical thinking skills and problem-solving had an average score of 3 with quite good criteria. Some indicators of this skill, namely: 1) using several types of reasoning types that are appropriate to the situation and conditions have an average score of 2.5 with quite good criteria; 2 ) processing and analyzing data effectively to determine decisions through arguments, having an average score of 3 with good enough criteria; 3 ) testing the information that has been processed and interpreted with the best analysis through initial conclusions having an average score of 3.5 with good criteria; and 4) identifying, analyzing, and solving a problem and having an average score of 2.8 with quite good criteria.
\end{abstract}

Keywords: vocational students, critical thinking skills and problem-solving

\section{INTRODUCTION}

The 21 st century is marked by massive changes namely a significant transformation due to the emergence of globalization. In this globalization era, all aspects of fulfilling the needs of knowledge-based life such as the development of a knowledge-based economy, the need for knowledge-based education, the development and empowerment of a knowledge-based society. Therefore, the 21 st century is also referred to as the era of knowledge (Mukhadis, 2013).

In the era of knowledge, there is an acceleration in the increase in knowledge due to rapid technological advances. The application of sophisticated digital media and technology supports the accelerated increase in knowledge so that the learning activities of the knowledge era must adjust to the needs of the knowledge era. In addition, every aspect of life requires high quality human resources and reliable capabilities. At present, competition for human resources is getting tougher. Many new jobs have sprung up in the industrial world. Some of these jobs require qualifications that workers do not have in general because all aspects are knowledge-based. These workers need to be equipped with formal education to acquire and implement 21 st century skills while engaging in the industrial world.

The21st Century skills exist in the midst of human resource needs that must meet the demands of the $21 \mathrm{st}$ century, namely the mastery of technology and knowledge. 21st Century skills are also present in the midst of 21 st century learning namely learning that uses aspects of skills, attitudes, knowledge, and skills in the use of technology, information, and communication. Based on the presentation of Triling and Fadel (2009), 21st century learning requires students to have three 21 st century skills, namely: 1) learning and innovation skills; 2) skills in using technology and information (information media and technology skills); and 3) life and career skills. Learning and innovation skills have three descriptions, namely: 1) critical thinking and problem solving; 2) communication and collaboration; 3) creativity and innovation. These skills make changes to learning activities. The intended learning is not only learning about knowledge, it is different about the process of forming knowledge by students through cognitive performance, namely learning to stimulate and develop students' critical thinking skills. These activities, can help students gain knowledge based on their own experience and understanding. Therefore, learning is not just a knowledge transfer activity but an activity that students need to do actively to construct the learning based on its potential (Abidin, 2014).

All 21 st century skills need to be mastered by students, including critical thinking skills and problem solving. Critical thinking skills consist of the ability to identify and analyze information that can be a learning material to abilities that need to be mastered. Critical thinking skills also represent other 21 st century skills such as analysis and evaluation skills, communication and information skills. Critical thinking skills and problem solving are 
error level of 5\%. Total population of 413 respondents. Then, the total sample of 191 respondents then to take the sample using two methods. The first method is cluster random sampling, taking samples from randomly selected population groups. The second way is proportionate random sampling, which is to take samples in a population group that is chosen randomly and proportionally. Data collection techniques using a questionnaire. The questionnaire used was a closed questionnaire using a questionnaire. Data analysis uses descriptive percentage analysis.

\section{RESULTS AND DISCUSSION}

Critical thinking skills and problem solving have four indicators. The first indicator is to use several types of reasoning types that are appropriate to the situation and conditions. The second indicator is to analyze and process data effectively to determine decisions using arguments. Joy indicators are testing the information that has been processed and interpreted with the best analysis through initial conclusions. The fourth indicator is identifying and solving a problem. Data on the average results of critical thinking skills and problem solving in detail can be seen in Table 1. academic year 2018/2019 consisting of SMKN 2 Malang, SMKN 3 Malang, SMKN 7 Malang, SMK Cor Jesu, and SMK Kartika IV-I Malang. Whereas the determination of the sample uses tables determining the number of samples of Isaac and Michael from a certain population with an

Table 1. Critical Thinking Skill and Problem Solving

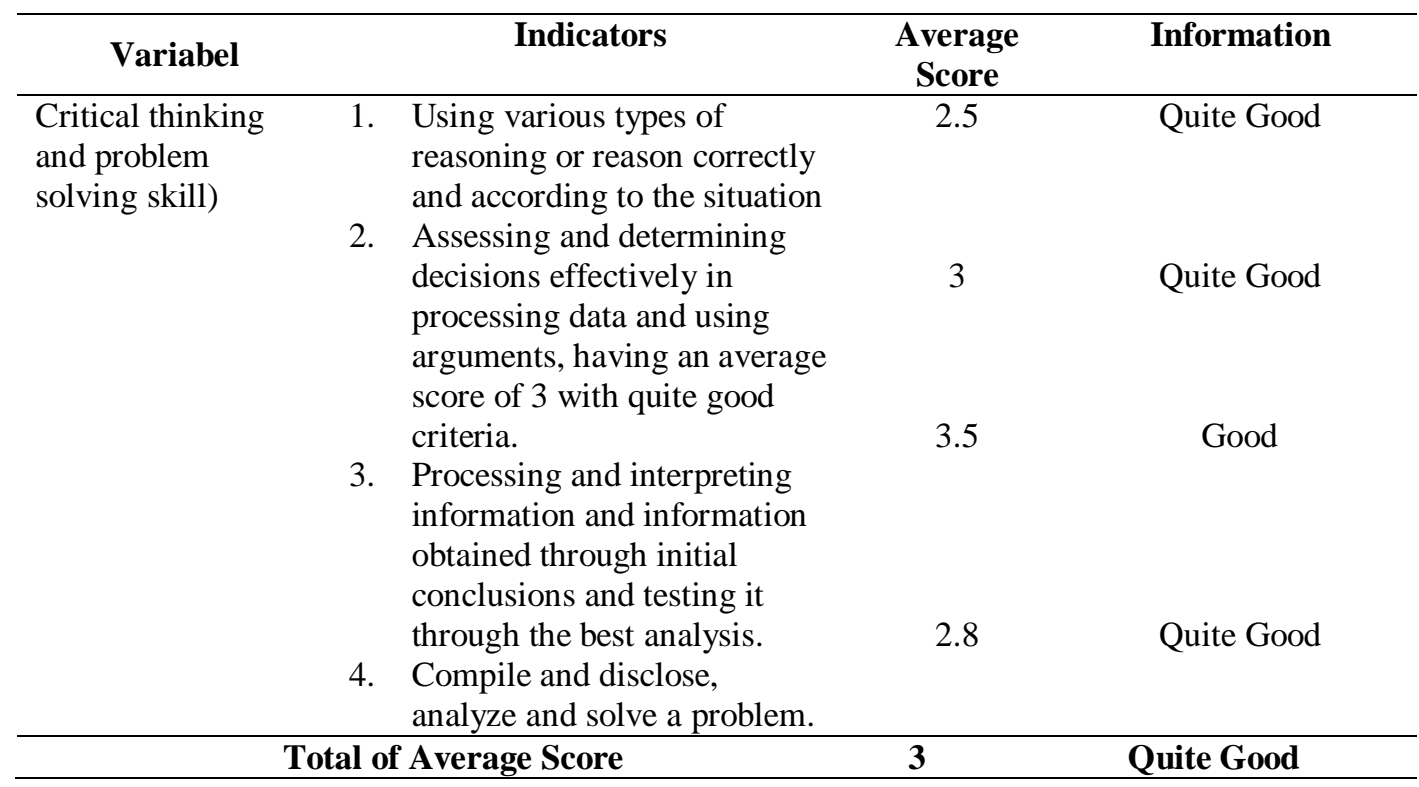

Table 1. shows the results of the study of critical thinking skills and problem solving obtained by students of SMK Culinary Art in Malang in quite good category. Critical thinking skills and problem solving have not reached very good criteria, it is assumed that the teacher is not optimal in applying learning models that can foster students in critical thinking and problem solving. Learning models that are able to grow the skills above include Problem Based Learning (PBL), namely problem-based learning that is able to direct so students can construct their own knowledge. The problems raised by PBL are real problems in daily life. The problems raised also do not have a single 
answer, meaning that students must explore multiple solutions. In problem solving activities, students are required to be able to develop critical thinking skills as a step to solve the problems discussed and to draw conclusions based on their understanding. As in learning basic food theory, the teacher can give a case to students such as the equipment that a Chef needs when making a beef steak brown sauce dish. Students can be divided into groups so that they can collaborate so students will interact, exchange ideas with the results of critical thinking to solve a case. This certainly provides a more complex learning experience for students. In accordance with Fakhriyah's research (2014), PBL learning models can improve high-level critical thinking skills, develop inquiry, and organize their own knowledge. The steps of PBL learning begin with asking questions, then focusing on the problem, investigating a problem, generating solutions or alternative answers, and collaboration between friends. Students are also freed to get information related to the problem they want to solve. Therefore, PBL is considered as a learning model that is able to encourage to improve critical thinking skills in solving problems.

The first indicator is to use several types of reasoning types that are appropriate to the situation and conditions obtained by students of SMK Culinary Art in Malang in quite good category. Students of SMK Culinary Art in Malang have not reached very good criteria on critical thinking skills and problem solving with indicators using several types of reasoning types that are appropriate to the situation and conditions, even though these skills are needed in facing the globalization era with all challenges and problems students will face. The above skills have not reached very good criteria, it is suspected that the teacher is not optimal in applying learning models that can improve students' reasoning skills. Learning models that can improve skills using various types of reasoning or reasoning appropriately and according to the situation include Brain Based Learning (BBL). The learning model can improve students' critical thinking skills and mathematical reasoning as well as create active and fun learning conditions that involve students. Brain-based learning does not emphasize on memorization but on the meaning of learning. The learning is learning that is constructivist and relaxed, there are also aspects of collaboration between students. In the subject of nutrition, there are calculations that require a high level of reasoning, namely the chapter Nutrition Adequacy Numbers (AKG). The AKG calculation questions received by students are problems that require collaboration between students to solve them. The questions are in addition to adjusting to the facts of daily life also requires full concentration to get the answer because the calculations used must understand about the AKG concept. The teacher needs to create a classroom atmosphere that challenges students' thinking abilities but is also fun. The questions that are packaged are made as interesting as possible, not just a matter of description but also in the form of games, puzzles, and so on. In line with Nahdi's research (2015), the average critical thinking skills and systematic reasoning of students in BBL classes are higher than conventional classes. This is because a lot of learning activities on the BBL model can support the development of students' critical thinking skills and mathematical reasoning. These learning activities include students guided by the teacher to discuss in groups in order to understand the material provided. Students are given projects or cases in the form of Student Worksheet (LKS) questions, puzzles and games whose function is to facilitate students building their knowledge and understanding based on their own learning experiences. The second indicator is to analyze and process data effectively to determine decisions using arguments obtained by students of SMK Culinary Art in Malang in the good enough category. Students of SMK Culinary Art in Malang have not reached the very good category, even though this skill is needed by students to prepare themselves for various kinds of problems in the globalization era. Only individuals who have the ability to think critically and creatively will survive in the midst of intense competition. The above skills have not yet reached the very good category, it is assumed that the teacher is not optimal in applying learning that can support these skills, such as the guided inquiry learning model. This learning model can be applied to certain learning such as Food Safety (Sanitation, Hygiene, and Work Safety). Guided inquiry learning is a learning model that provides opportunities for students to be active in learning so as to be able to understand concepts well and develop critical thinking skills guided by the teacher. One phase of inquiry learning is collecting and processing data. In the subject of food safety, there are many cases that need to be studied by students, one of which is the risk of hygiene related to food poisoning. Students need to be equipped with dangers if hygiene is not applied to the food served. To understand the danger or risk, the teacher can conceptualize guided inquiry learning. Thus, students get exploratory information related to food hazards if hygiene is not applied, with the guidance of the teacher. Students are able to get answers about these precautions. This is similar to the study of Falahudi et al (2016), when applying the guided inquiry learning model to students getting very good percentage results is greater than the percentage of very good at ordinary discussion learning. In guided inquiry learning, students actively participate in learning so as to increase interest and motivation to learn, students are able to find their own concepts. Students search for information and conduct experiments so that it is easier to find certain concepts or principles. The use of worksheets stimulates students to do activities in accordance with learning. This activity is a more effective tool because it provides more opportunities for students to develop their thinking, and the teacher is only as a facilitator in developing students' thinking.

The third indicator is testing the information that has been processed and interpreted with the best analysis through the initial conclusions obtained by students of SMK Culinary Art in Malang in the good category. The above skills have not yet reached the very good category, it is suspected that the teacher was not optimal in implementing the Learning Implementation Plan (RPP) in 
score of 2.5 with quite good criteria; 2) analyze and process data effectively to determine decisions using arguments, having an average score of 3 with quite good criteria; 3 ) testing the information that has been processed and interpretation with the best analysis through initial conclusions has an average score of 3.5 with good criteria; and 4) identify and solve a problem and have an average score of 2.8 with quite good criteria.

\section{REFERENCES}

[1] Abidin. 2014. Desain Sistem Pembelajaran dalam Konteks Kurikulum 2013. Bandung: Refika Aditama.

[2] Fakhriyah, F. 2014. Penerapan Problem Based Learning dalam Upaya Mengembangkan Kemampuan Berpikir Kritis Mahasiswa. Jurnal Pendidikan IPA Indonesia, 3(1), 95-101. Dari http://journal.unnes.ac.id/nju/index.php/jpii

[3] Falahudin, Irham., Wigati, Indah., Pujiastuti. 2016. Pengaruh Model Pembelajaran Inkuiri Terbimbing terhadap Kemampuan Berpikir Kritis Siswa pada Pembelajaran Materi Pengelolaan Lingkungan Di SMP Negeri 2 Tanjung Lago, Kabupaten Banyuasi, Jurnal Bioilmi, 2(2), 92- 101 . Dari http://jurnal.radenfatah.ac.id/index.php/bioilmi/arti cle/view/1133

[4] Machin, A. 2014. Implementasi Pendekatan Saintifik, Penanaman Karakter dan Konservasi pada Pembelajaran Materi Pertumbuhan, Jurnal Pendidikan IPA Indonesia, 3(1), 28-35. Dari http://journal.unnes.ac.id/nju/index.php/jpii/article/ view/2898

[5] Mukhadis Amat. 2013. Sosok Manusia Indonesia Unggul dan Berkarakter dalam Bidang Teknologi sebagai Tuntutan Hidup di Era Globalisasi. Jurnal Pendidikan Karakter, 3(2), 115-136. Dari https://journal.uny.ac.id/index.php/jpka/article/vie w/1434/1222.

[6] Nahdi, S. Dede. 2015. Meningkatkan Kemampuan Berpikir Kritis dan Penalaran Matematis Siswa melalui Model Brain Based Learning. Jurnal Cakrawala Pendas, 1(1), 13-22, Dari https://jurnal.unma.ac.id/index.php/CP/article/view 1341

[7] Ninik., Hobri., Suharto. Analisis Kemampuan Pemecahan Masalah untuk Setiap Tahap Model Polya dari Siswasmk Ibu Pakusari Jurusan Multimedia pada Pokok Bahasan Program Linier, Jurnal Matematika dan Pendidikan Matematika, 5(3), 61-68. Dari https://jurnal.unej.ac.id/index.php/kadikma/article/ view/1374

[8] Trilling, Bernie., Fadel, Charles. 2009. 21st Century Skill: Learning for Life in Our Times, John Wiley \& Sons, 978-0-47-055362-6. 